\title{
二次元矩形ノズルからの固気二相噴流とマイクロブラスト加エ*
}

\author{
杉 本 真 樹*1, 社河内 敏 彦*1 \\ 早 川 浩 平*2, 伊 澤 守 康*3
}

\section{Gas-Particle Two-Phase Jet Flow from Slot Nozzle and Micro-Blasting Process}

\author{
Masaki SUGIMOTO, Toshihiko SHAKOUCHI*4, \\ Kohei HAYAKAWA and Moriyasu IZAWA \\ ${ }^{* 4}$ Graduate School of Engineering, Mie University, \\ 1577 Kurimamachiya-cho, Tsu-shi, Mie, 514-8507 Japan
}

\begin{abstract}
Recently micro-blasting process has been widely used to process brittle material, and at that time a conventional circular nozzle was commonly used. But, the cutting performance of the circular nozzle does not process a large area well so the use of a slot nozzle is considered. In this study, in order to improve the cutting performance of the micro-blasting nozzle, a new slot nozzle with a large aspect ratio is proposed and the flow characteristics and cutting performance are examined precisely by experimental and numerical analysis. Main results show that (1) setting the circular vane in the slot nozzle perpendicular to the stream can diffuse particle flow uniformly at the nozzle exit and then particle velocity distribution becomes uniform, (2) expanding the nozzle outlet at an angle, uniform air and particle velocity distributions at the nozzle exit can be obtained, ( 3 ) in spite of setting obstacles in the nozzle, a fine cutting efficiency is obtained compared to the conventional microblasting circular nozzle.
\end{abstract}

Key Words : Multi-Phase Flow, Jet, Nozzle, Flow Control, Micro-Blasting

\section{1. 緒 論}

発展が著しい半導体や電気・電子産業を支える孔加 工, 溝加工などの加工技術として, 近年, 高精度, 高効 率の微細加工技術が強く求められている. 微細加工技 術にはウエット・ドライエッチング, レーザ, 放電, 超音波, ドリル加工などさまざまな手法があるが, 数 十 $\mu \mathrm{m}$ オーダの微粉粒子を含む固気二相衝突噴流を使 ったマイクロブラスト加工 [高速の固気二相噴流を加 工材料, 被削材 (ワーク)面に衝突させその際, 微粉粒 子の衝突によって加工面を微小破壊, 加工する加工法 で, 寸法精度は高精度のマスキングによって保障され る. 以後, micro-blasting process, 簡単のため MBP とも呼ぶ）は，特に脆性材料に対する微細加工技術と して高生産性, 低コストなどのためその使用が増大し ている(1).

従来, MBP 用ノズルとして円形ノズルが用いられ てきたが，ワークを広範囲に加工するためには何回も

$*$ 原稿受付 2005 年 2 月 21 日.

*1 正員, 三重大学大学院工学研究科( - 514-8507 三重県津市 栗真町屋町 1577).

*2 三重大学大学院工学研究科.

*3 新東ブレーター(株) (-881-8678 愛知県西春日井郡西春町 宇福寺福明 51).

E-mail : shako@mach.mie-u.ac.jp
のスキャンを必要とし生産性が劣る。また, 複数本の 円形ノズルを配置し生産性を向上させる手段もとられ るが, 装置コストの上昇, および装置の複雑化による メンテナンス性の悪化などが問題となる.

近年, ワークを広範囲に効率よく加工する方法とし て二次元形状の矩形断面ノズルの使用が考えられてい る(2). しかしながら, ノズル幅の全領域にわたり精度 の高い一様な加工深さを得ることは困難であり, 実用 的に満足する結果が得られていない.

本研究では, MBPにおいてワークの大きな面積を 高精度に効率よく加工するために幅の広い噴射口を有 する二次元形状の矩形断面ノズルを新たに提案し，ノ ズルからの高速空気噴流の流動特性, 微粉粒子の挙動 とワークの加工特性を実験的, 数值解析的に検討し た. その結果, ノズル幅の全域にわたり精度の高い加 工深さを得るノズルを実現した。

\section{2. 実験装置および方法}

$2 \cdot 1$ 供試ノズル 図 1 に供試ノズルと座標系を 示す. 図 1(a)には, 一般に使用されているディフュ 一ザの形状を参考に設計(3) した二次元形状の矩形出 口断面を有する供試基本ノズルを示す．ある一定の質 量比の微粉粒子を含んだ固気二相流が, 直径 $32 \mathrm{~mm}$ 


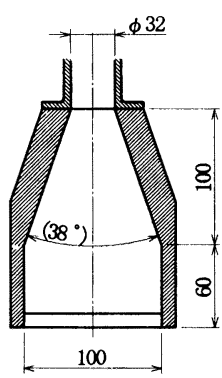

(a) 1st nozzle

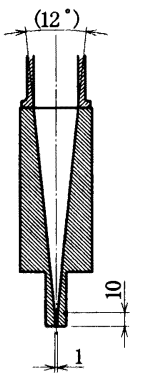

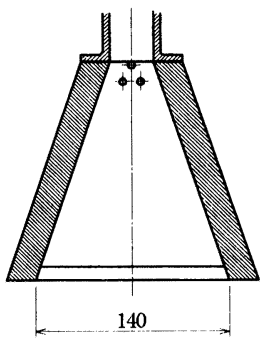

(d) 2nd nozzle

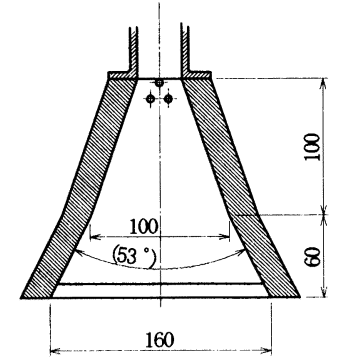

(e) 3rd nozzle

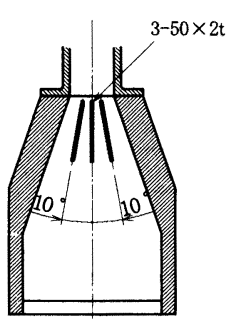

(b) 1st nozzle with plate vane

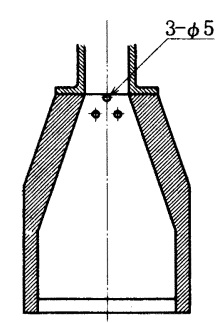

(c) 1st nozzle with circular vane

Fig. 1 Details of new rectangular nozzle

の円管から一辺が $32 \mathrm{~mm}$ の正方形入口断面を有する 供試ノズルへ流入し, 幅 $(y)$ 方向へ $100 \mathrm{~mm}$ の大きさ に広げられる(広がり角度, $\alpha=38^{\circ}$ )。そこからノズル 出口まで $60 \mathrm{~mm}$ の長さを, 幅 $100 \mathrm{~mm}$ で一定とした。 なお,ノズルの高さ $(z)$ 方向はノズル入口からノズル 出口上流 $10 \mathrm{~mm}$ まで直線的に $1 \mathrm{~mm}$ まで狭め, そこ から $10 \mathrm{~mm}$ の長さの平行部を設けた(以後, 第 1 ノズ ルと呼ぶ)。なお，ノズル上流部に，流れおよび粒子の 分散を一様にすることを目的にベーンを設けたものを 用意した. ベーンの形状はディフューザで一般に用い られている平板形状 (厚さ $2 \mathrm{~mm}$, 長さ $50 \mathrm{~mm}$ ) と円柱 形状（直径 $5 \mathrm{~mm}$ )のものを用いた [図 1 ( b ), (c)].

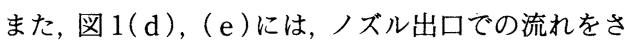
らに一様にすることを目的に考案したノズルを示す。

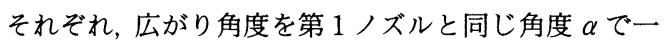
定としノズル出口幅を $140 \mathrm{~mm}$ としたノズル(第2 ズル），および途中から広がり角度をさらに大きくし ノズル出口幅を $160 \mathrm{~mm}$ にしたノズル(第3 ノズル) である。

図 1(f )に, 使用した記号の一部, および座標系を 示す. 座標系は, ノズル出口中心を原点 $o$ とし, 下流 方向を $x$, 幅方向を $y$, 高さ方向を $z$ とし, $x$ 方向速 度を $u$, 出口での最大流速を $u_{0}$, 中心線上の気体, お よび粒子速度をそれぞれ $u_{c}, u_{p, c}$ とする， $p_{0}, p_{\infty}$ は それぞれ空気供給圧力および周囲圧力である.

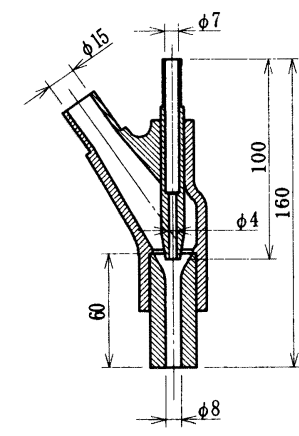

(a) Suction type nozzle

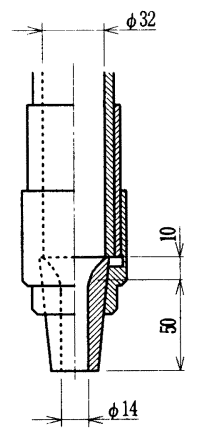

(b) Pressure type nozzle
Fig. 2 Conventional nozzle

また, 加工特性を比較するために, 図 2 に示す従来 から MBP に広く用いられている円形状の噴出口を有 するMBP用ノズルも用いた。図 2(a)，(b)はそれ ぞれ，吸引方式で粒子を供給するノズルおよび粒子を 加圧下で圧送するノズルである.

$2 \cdot 2$ 実験装置ブロワおよびコンプレッサによ って加圧された空気は, インバータ, バルブを使って 流量を調節され，ノズルから静止大気中に噴出され る. 噴流温度 $T_{a}$ は, ノズル上流のパイプの管内壁に 設置した熱電対によって測定した. また，ノズル内お よび管内の圧力は, 内壁に設置した内径 $0.8 \mathrm{~mm}$ の静 圧孔を使って測定した。 
Table 1 Test condition

\begin{tabular}{|l|l|}
\hline \multicolumn{1}{|c|}{ Item } & \multicolumn{1}{c|}{ Data } \\
\hline Particle (abrasive) & $\begin{array}{l}\text { JS-GC\#600 } \\
\text { (Ave. dia. } 25 \mu \mathrm{m}) \\
\text { Specific gravity }: 3170 \mathrm{~kg} / \mathrm{m}^{3}\end{array}$ \\
\hline Loading ratio, $L R$ & $0.06 \sim 0.38$ \\
\hline Impinging distance, $H$ & $15 \mathrm{~mm}(H / h=15)$ \\
\hline Supplied pressure, $\left(p_{0}-p_{\infty}\right)$ & $0.025 \sim 0.200 \mathrm{MPa}$ \\
\hline Workpiece transfer speed & $3 \mathrm{~mm} / \mathrm{sec}$ \\
\hline Workpiece material & Soda lime glass $\left(\mathrm{Na}_{2} \mathrm{CaO} 5 \mathrm{SiO}_{2}\right)$ \\
\hline
\end{tabular}

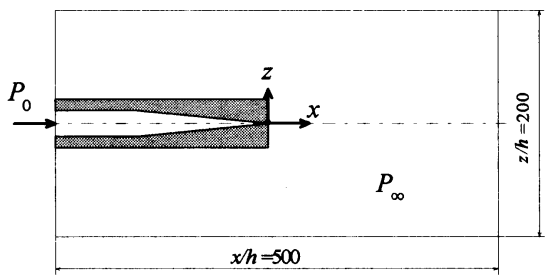

Fig. 3 Computational domain

噴流の速度分布 $u$ の測定は, 直径 $0.8 \mathrm{~mm}$ のピト 一総圧管を使って測定した。その際, 圧縮性の影響を 考慮した. なお, 第 2,3 ノズルでは速度が $y$ 方向成 分を有するため, その向きは短いタフト, 系を使って 測定した。

マイクロブラスト加工 (MBP) 実験では, まず, 被削 材としてガラス板を主流方向に対してノズル・平板間 距離 $H / h=15$ で垂直に設置した. 次いで, ノズル上 流で粉体がスクリュー式定量供給装置により供給量平 均值に対して土5\%以下の精度である一定量が供給さ れ，ノズル出口でほぼ均一な濃度の固気二相流となっ て噴出し, 被削材に衝突する.その際, ノズルは固定 され, 被削材が $z$ 方向に一定速度 $3 \mathrm{~mm} / \mathrm{s}$ で移動され る. 加工深さは MBP で得られた被削材加工部の加工 断面を触針式表面粗さ計 (東京精密, SURFCOM 1400 D) で測定して求めた。 なお，加工深さ精度 $\zeta[\%]$ は 加工平坦部長さ $l_{i}$ にわたる加工深さの平均値 $\bar{d}$ に対 する加工深さばらつきの割合を示し式 ( 1 )で求めた.

$$
\zeta= \pm\left(\frac{d_{\text {max. }}-d_{\text {min. }}}{2 \bar{d}}\right) \times 100
$$

ここで, $d_{\max }$ および $d_{\min .}$ はそれぞれ $l_{i}$ における最大 加工深さ, 最小加工深さである.

被削材の除去重量は精密電子天秤 (A \& D, GR200)を用いて, 粒子直径はレーザ回折型粒度分布測定 器 (堀場, LA-300) を使って測定した. なお, 本文中の 粒子直径は平均粒子直径を示す.

粒子の挙動, 速度の測定には, CCD カメラからの画
像データを PIV 装置(TSI, 2 D PIV System)を用い て処理することから求めた. 流れ場の可視化用光源と して Nd-Pb YAGレーザ(照射強度： $15 \mathrm{~mJ} / \mathrm{cm}^{2}$ )を 用いた。広角レンズによってシート状に広げられたレ ーザ光は, 時間間隔 $3.0 \mu \mathrm{s}$ で照射され，流れ場の $(200 \times 260 \mathrm{~mm})$ の領域を CCD カメラで撮影し, 粒子 の速度ベクトルの解析は $(1.0 \times 1.0 \mathrm{~mm})$ の格子に区 切って行った. なお, 解析は各条件で 50 回(100フレ 一ム) 行い, 各セルのベクトル平均值を実験值として 用いた。 また, 固気二相噴流中の粒子分布を観察する ために噴流にレーザを照射し， CCD カメラで粒子画 像を撮影した。

$2 \cdot 3$ 実験条件 表 1 に, 供試粒子特性および実 験条件を示す．空気単相流の速度分布などの測定実験 では，ノズル上流での空気供給ゲージ圧を $\left(p_{0}-p_{\infty}\right)=$ $0.025 \mathrm{MPa}\left(u_{0}=200 \mathrm{~m} / \mathrm{s}\right)$ とし, $\mathrm{MBP}$ 実験では $\left(p_{0}-\right.$ $\left.p_{\infty}\right)=0.100 \mathrm{MPa}\left(u_{0}=360 \mathrm{~m} / \mathrm{s}\right)$ として噴射加工実験 を, また加工効率測定実験では $\left(p_{0}-p_{\infty}\right)=0.050$ $0.200 \mathrm{MPa}$ と変化させて行った。供試粒子は市販の 炭化ケイ素研摩材で，ノズル出口での粒子の速度べク トルの測定では混合比を $L R=0.06=$ 一定とし, $\mathrm{MBP}$ 実験では $L R=0.10=$ 一定, 加工効率評価に際 しては粒子供給量を $1000 \mathrm{~g} / \mathrm{min}$ で一定とした $(L R=$ $0.15 \sim 0.38$ ).

\section{3. 数 值 解 析}

本研究ではノズルの設計に際し, 各種パラメータの 影響を考慮する際の参考にするため, 質量保存則およ び運動量保存則から構成される連続式とナビエ・スト ークス方程式を数值的に解くための汎用流体解析ソフ ト(Fluid Technology, CFD 2000)を用い,ノズル内 およびノズルからの噴流の流動特性を数值的に解析し 実験結果と比較・検討した。なお，乱流解析は乱流運 動エネルギー $k$ と乱流散逸率 $\varepsilon$ に対する輸送方程式 を解く標準乱流 $k-\varepsilon$ モデルとした.

図 3 に, 計算領域および座標系を示す.計算領域は ノズル中心断面(二次元, $x-z$ 面, $y=0$ )について $500 \times 200 \mathrm{~mm}$ の領域を, $150 \times 100$ の不等間隔格子で 分割し, 境界条件はノズル入口に $\left(p_{0}-p_{\infty}\right)=0.025$ $\mathrm{MPa}=$ 一定の圧力流入条件を, ノズル出口境界で大 気圧とする圧力流出条件を与えた.

粒子の速度分布の計算は単一球形粒子が粒子間およ び壁面との衝突なしに流下するとした。なお，粒子と 流れとの間の干涉も無視した(one way method). 


\section{4. 実験結果および考察}

$4 \cdot 1$ 第 1 ノズルの加工性能図 4 に, 第 1 ノズ ルの加工断面形状を示す. 加工断面はノズル幅中心 $y / h=0$ を極大とする比較的対称性のよい凹面形状と なった.また，図 5,6 にそれぞれ，第1ノズルの空気 自由流の速度分布，および粒子分布と粒子の速度心゙ク トルを示す。いずれも中心線に刘して対称な分布形で あったので, $y$ 方向に半分の領域のみを示した。

空気噴流の速度分布 $u / u_{0}$ はノズル幅方向端部でい くぶん速度が大きい鞍形分布となる。また, 一点鎖線 で示す平坦な速度分布の噴流幅は噴流端部が周囲流体 とのせん断力によって減衰するため, 下流にいくにし たがい減少する。

粒子濃度はノズル幅中心部 $y / h=0$ で最も大きく, ノズル幅方向端部にいくにしたがって減少し, $y / h \leq$ -35では粒子を確認できない程度に希薄になる。こ れは粒子の慣性力が大きいため粒子が $y$ 方向にあま り拡散せず流下することによる。また, 粒子の速度は, ノズル中心 $y / h=0$ を最小としてノズル端にいくにし たがって大きくなる凸状形を示し，下流では粒子は中 心方向へ向かうことがわかる. なお, 中心部では粒子 数密度が大きいため, 粒子間干渉, 衝突により粒子速 度が低下すると考えられる。

これらの結果から, ノズル幅 $( \pm y)$ 方向への気体速 度分布の不均一性や粒子数密度の差異, その差異によ る粒子間干渉, 衝突の差異が原因として生じる粒子速 度の差異が, 加工精度を支配していると考えられる。 したがって, 加工精度を向上させるには, 土y方向へ の粒子濃度分布を均一化および気体速度分布の均一化 が肝要である。

$4 \cdot 2$ 粒子濃度分布の均一化 $\pm y$ 方向八粒子を 分散させ粒子濃度分布を均一化するために, 図 1 ( b ), (c)にそれぞれ示した平板および円柱形状ベーンを使 用した。なお, 各種ベーンの挿入によって単相空気噴 流の流動特性(平均, および変動速度分布)にほとんど 変化はなかった.

図 7(a)，（b）にそれぞれ，平板および円柱形状心゙ ーンを挿入したときの粒子の速度べクトル, 濃度分布 を示す. 平板形状ベーンの場合, 粒子濃度は $y$ 方向へ 広がるが, ベーン下流では粒子濃度が希薄になる。ま た, 粒子の速度分布はその粒子濃度の不均一性に伴う 粒子間干涉の差異から, 粒子が希薄な領域は粒子速度 が大きく, 粒子が濃厚な領域は粒子速度が小さくなる ように粒子濃度分布にならって山凸(大小)が顕著に生 じる.

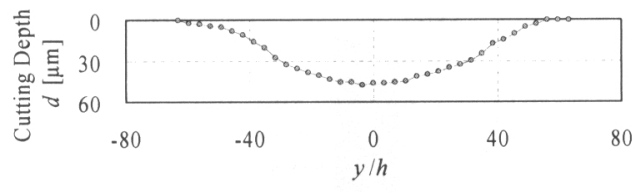

Fig. 4 Cutting cross section by MBP (1st nozzle)

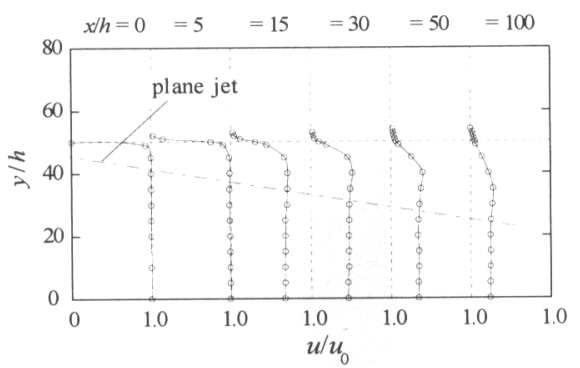

Fig. 5 Velocity distribution of air free jet (1st nozzle)

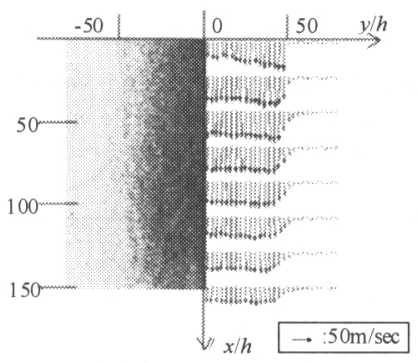

Fig. 6 Particle concentration and velocity vector of free jet (1st nozzle)

円柱形状ベーンの場合の粒子濃度は, ノズル両端部 の比較的濃度の高い部分を除いて均一な分布形となっ ている. 粒子速度分布も粒子間干渉の均一化にしたが って, 平坦性, 均一性の高い分布形となる。

図 8(a)，(b)にそれぞれ平板抢よび円柱形状べー ンの場合の MBPによる加工断面形状 $(z=0)$ を示す. 各加工断面形状は粒子濃度分布にならって, 粒子が希 薄な部分は浅く, 粒子が濃厚な部分は深い山凸形状と なるのがわかる.平板形状べーンの場合, $-40 \leq y / h \leq$ 40 で加工精度は $= \pm 60 \%$ となるが, 円柱形状ベーン では $-40 \leq y / h \leq 40$ で $\zeta= \pm 7.5 \%$ なり, 円柱形状 ベーンの核うが粒子を拡散, 均一化させるのに優れて いることがわかる。

次に, 各ノズルの MBP 加工量と運転動力との関係 について述べる.なお, 運転動力 $W$ はノズル部の流 動損失 $\left(p_{0}-p_{\infty}\right)$ と流量との積として求めた.

図 9 にその結果を示すが, 円柱形状ベーンが最も大 きい加工量を得ることができ, 例えば運転動力 $W=5$ 


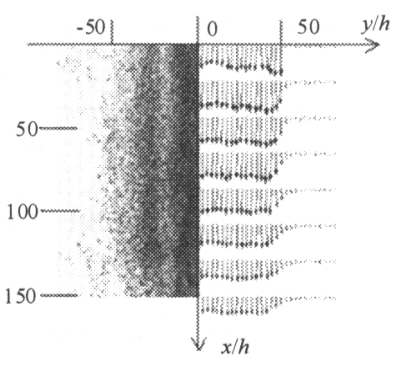

(a) 1st nozzle with plate vane

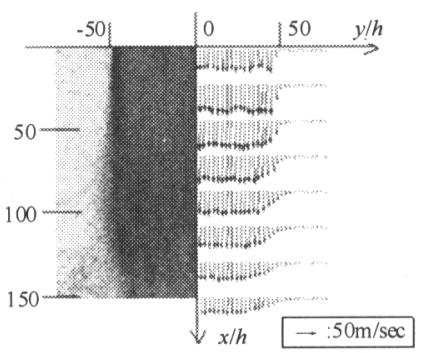

(b) 1st nozzle with circular vane

Fig. 7 Particle concentration and velocity vector of gas-solid free jet (1st nozzle with plate or circular vane)

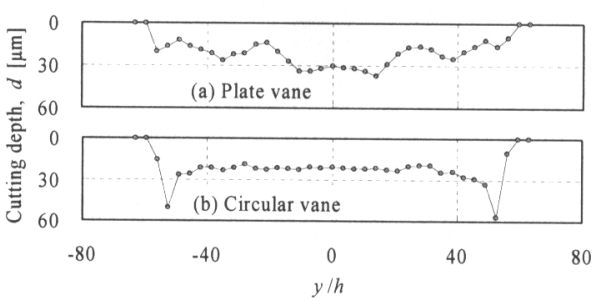

Fig. 8 Cutting cross section for each vane (1st nozzle)

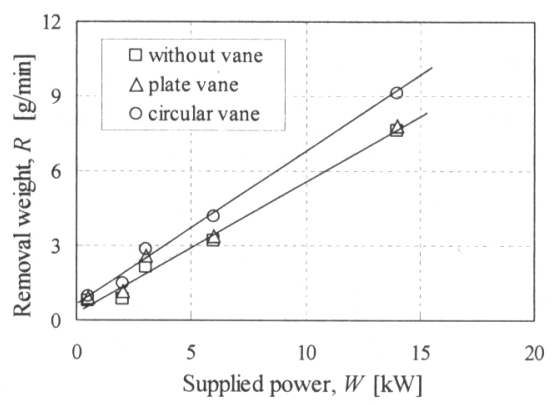

Fig. 9 Cutting efficiency for each vane (1st nozzle)

$\mathrm{kW}$ の場合に基準となるベーンを有しないノズルに対 して平板形状ベーンではその差異はほとんど見られな いが, 円柱形状心゙ーンについては約 30\%の効率向上が 見られる。これは, 粒子濃度を拡散, 均一化させるこ とによって固気二相噴流内での粒子間干渉が低減さ

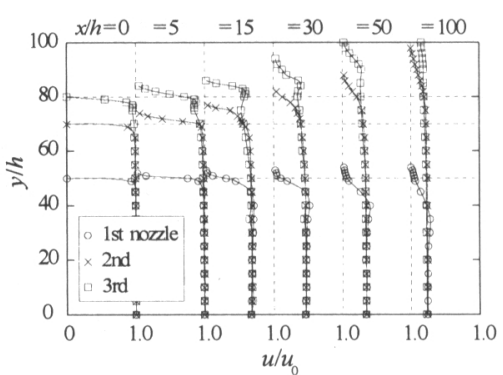

Fig. 10 Velocity distribution, $u / u_{0}(x-y$ plane, $z=0)$

れ，また加工面へ衝突した後の粒子および加工除去さ れた粒子の加工面からの排出がスムーズに行われるこ とが原因と考えられる。

したがって, 粒子濃度を拡散, 均一化させると加工 精度を向上させるだけでなく, MBP の効率も向上さ せることができる。

\section{$4 \cdot 3$ 気体速度分布の均一化と加工性能 ，ズル}

内に円柱を挿入した第 1 ノズルをもとに作成した出口 を広げたノズル [図 1(d), ( e ) ] の, 速度分布の均 一化と MBP 加工特性との関係を検討する。

$4 \cdot 3 \cdot 1$ 速度分布, $x-y$ 面 $(z=0)$ 図 10 亿, 各) ズルの場合の空気自由噴流の速度分布 $(x-y$ 面, $z=0)$ の実験結果を示す。ノズル出口では，いずれのノズル の場合もノズル幅全体にわたって一様な速度分布をも つが，下流にいくにしたがって各ノズルで差異が見ら れる.

第 1 ノズルは, 先述したように, 一般的に矩形噴流 の特徴として知られている鞍形の速度分布形状を示す ため, 速度が均一で平坦な部分は少ない.

第 2 ノズルは, ノズル入口から出口まで一定の角度 で広げられているため, 速度分布は鞍形を示さず, 広 い範囲でほぼ一様になる.また, ノズル出口速度に y 方向速度成分をもち，第 1 ノズルに対して速度分布の ノズル端部での減衰が䋸やかになる。

第 3 ノズルは，第 2 ノズルに比べノズル出口で角度 がさらに広げられるため, 気体が壁面付着していると 考えられる。そのため, ノズル端部近傍で速度が減衰 したあと, 外縁で再び極大值が現れる。しかしながら， 速度分布は高い平坦性を有しその幅は最も大きい.

これらの結果から, 実際に衝突噴流として適用する には, ノズル出口近傍 $(0 \leq x / h \leq 15)$ では第 2 ノズル を,さらに下流 $(30 \leq x / h)$ においては第 3 ノズルを用 いると, より広い範囲で一様な速度分布を有する噴流 が得られる。

次に, 各ノズルの流動特性をさらに詳細に明らかに 


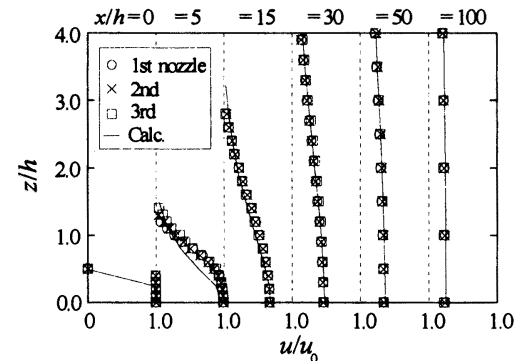

Fig. 11 Velocity distribution, $u / u_{0}(x-z$ plane, $y=0)$

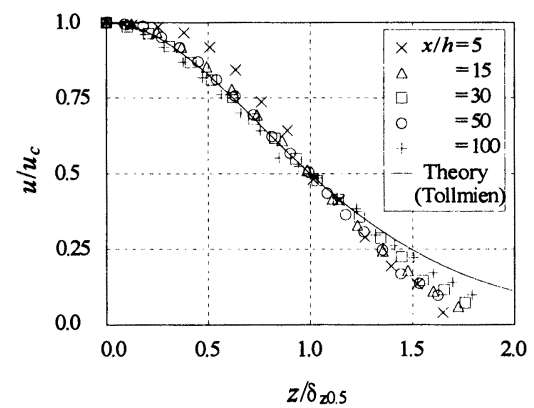

Fig. 12 Velocity distribution, $u / u_{0}(x-z$ plane, $y=0)$ (3rd nozzle)

するため空気自由噴流の $x-z$ 面 $(y=0)$ の速度分布な どを示す。

$4 \cdot 3 \cdot 2$ 速度分布, $x-z$ 面 $(y=0)$ 図 11 に, ノズ ル中心軸面 $(x-z$ 面, $y=0)$ の速度分布を示す. 分布 形は $x$ 軸に対して対称であったので, $z$ 方向に半分の 領域のみを示した。いずれのノズルの場合も速度分布 形はほほ一致し，ノズル出口で矩形形状の速度分布が 下流に向かって中心線流速を隇衰させながら $z$ 方向 に緩やかに広がる。なお，図 11 中の曲線は数值解析 結果であるが,ノズル出口近傍を除いて実験結果とよ く一致する。

図 12 に, 一例として第 3 ノズルの速度分布を, 中心 線流速 $u_{c}$ と噴流の半值幅 $\delta_{z 0.5}$ で無次元化した結果を 示す. $x / h>15$ の発達領域での速度分布は噴流外縁部 を除きほほ相似形となる。なお，図 12 中の実線は二 次元自由噴流に対する Tollmienの速度分布理論曲 線(4)を示すが，噴流外縁部を除き発達領域での速度分 布をほほよく表す。

このように, 噴流は $\pm z$ 方向 $(y=0)$ へほほ二次元自 由噴流の速度分布をもって流下する。

$4 \cdot 3 \cdot 3$ 噴流幅 図 13(a)に, 幅 $(y)$ 方向の噴流 幅 $\delta_{y}$ を半值幅 $\delta_{y 0.5}$ とともに示す。なお，噴流幅 $\delta_{y}$ は $u=0.1 u_{c}$ の位置を噴流外端として求めた.

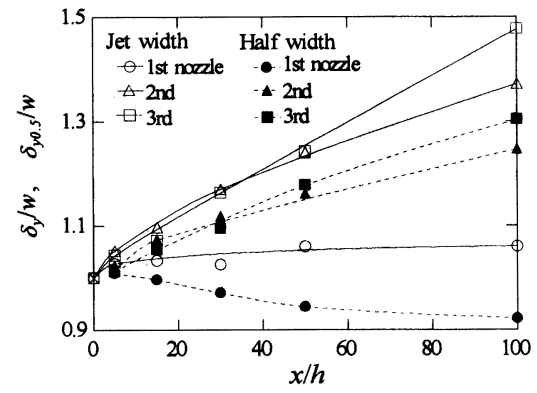

(a) $\delta_{y} / w, \delta_{y 0.5} / w,(x-y$ plane, $z=0)$

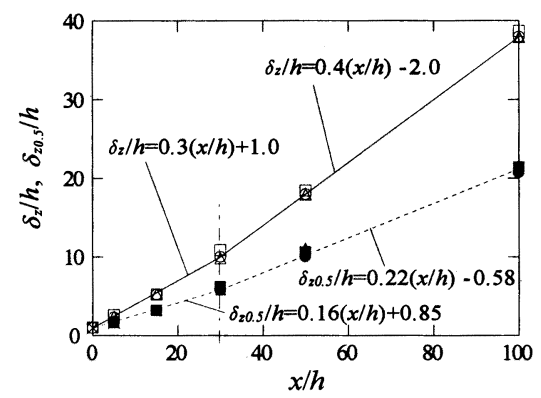

(b) $\delta_{z} / h, \delta_{z 0.5} / h,(x-z$ plane, $y=0)$

Fig. 13 Spread of jet

第 1 ノズルでは，その形状のため噴流が $y$ 方向にあ まり広がらないが, 第 2 , 第 3 ノズルではノズルが出 口近傍でも広がっているため $\delta_{y}$ はかなり大きい.

第 2 ノズルでは第 3 ノズルに比べ上流部での広がり が大きい.また，その結果，そこでの運動量の減衰も 大きいため下流での広がりが小さくなる.なお，第 1 ノズルの半值幅は $\delta_{y} / w<1$ で, 下流にいくほど小さく なる.すなわち, 速度分布の平坦な分布の範囲が他の ノズルに比べ小さいのがわかる.

図 13(b)に, 高さ $(z)$ 方向の噴流幅 $\delta_{z}$ を半値幅 $\delta_{z 0.5}$ とともに示す.いずれの場合も噴流は下流に向 かって直線的に広がり，それらの関係は次式で表され る.

$$
\begin{array}{rlrl}
\delta_{z} / h & =0.3(x / h)+1.0 & & (x / h \leq 30) \\
& =0.4(x / h)-2.0 & & (x / h \geq 30) \\
\delta_{z 0.5} / h & =0.16(x / h)+0.85 \cdots(2) \\
& =0.22(x / h)-0.58 & & (x / h \leq 30) \\
& (x / h \geq 30) & \cdots(3)
\end{array}
$$

$\mathbf{4 \cdot 3 ・ 4}$ 粒子の挙動 図 14 に, 第 2 , 第 3 ノズル の場合の粒子濃度分布と粒子速度べクトルを示す。， ズル内部に円柱形状ベーンが挿入されているため, 両 ノズルともに粒子濃度はノズル幅全域にわたってほほ 均一である. 図7(b)に示したように，ノズル端部で 粒子濃度の高い領域がノズル端部を広げることによっ て拡散し均一な粒子濃度分布が澾成されたものと考え 


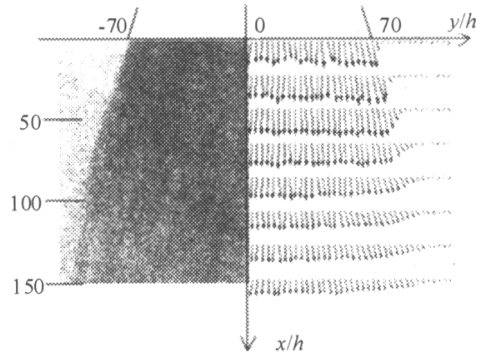

(a) 2nd nozzle

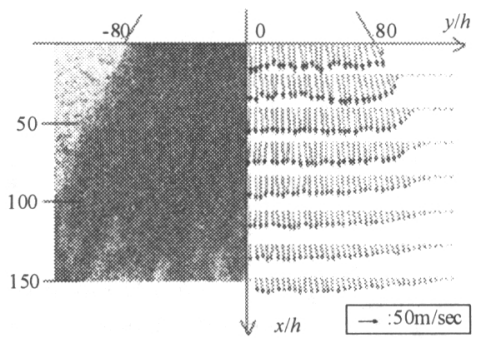

(b) 3rd nozzle

Fig. 14 Particle concentration and velocity vector of particle laden free jet

られる。

粒子速度べクトルの大きさは, 第 1 ノズルの場合と 同じように粒子分布の均一化によりほぼ均一な分布を 示したが，その方向が第 1 ノズルが内側への向きをも つのに対し，第 2 , 第 3 ノズルではともに外側への向 きをもつ。

$4 \cdot 3 \cdot 5$ 固気二相自由噴流の流動特性 図 15 に, 第 3 ノズルの場合の粒子と気体の $x$ 方向速度分布 $(x-y$ 面, $z=0)$ を示す. 気体の速度分布は, 固気二相 噴流の場合と同一流量での空気単相流の結果である. 粒子の $y$ 方向への広がりは気体のそれとほぼ同様で, $y$ 方向に広く均一な速度分布を有している.

図 16（a）に，実験および数值計算によって得られた ノズル中心軸上の気体と粒子の速度分布 $u_{c}, u_{p, c}$ を 示す.

Uc はノズル出口に向かって等エントロピー的に膨 張, 急加速され, ノズルから噴出された後は後述する ように二次元噴流の速度分布と一致して減衰する。な お, 数值解析結果は実験結果をよく表す. 一方, 粒子 は気体と比較して比重が大きいため, $u_{p, c}$ はノズル直 後では気体速度の $20 \%$ 程度しか加速されておらず，そ の後は相対的に大きな速度を有する気体からの抵抗を 受けて加速が継続され, $x / h \fallingdotseq 40$ で最大となり, 以後 気体速度の減衰に従って緩やかに減衰する。なお, 図

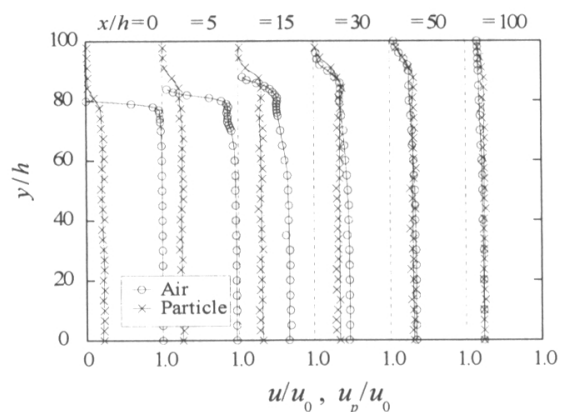

Fig. 15 Particle velocity distribution of 3 rd nozzle

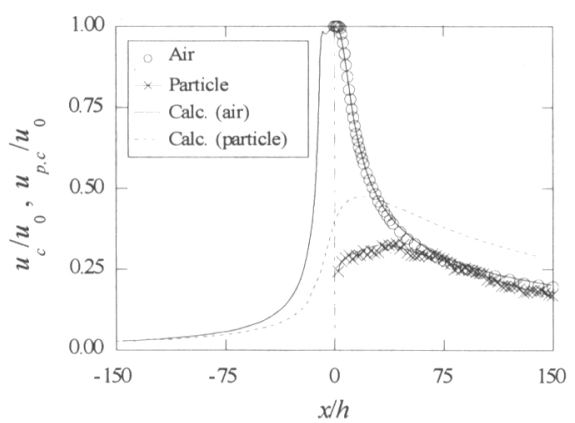

(a) Velocity distribution

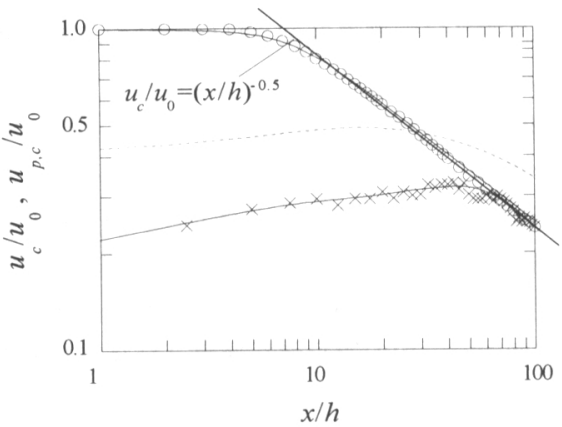

(b) Velocity distribution, logarithmic plot

Fig. 16 Centerline air and particle velocity distributions of 3 rd nozzle

15 中の破線は $u_{p, c}$ の計算結果であるが, ノズル出口 で実験值の約 2 倍となり大きく異なる.これは, 先に 述べたように計算における種々の仮定, 例えば, 単一 球形粒子が粒子間抢よび壁面と衝突なしに流下するな どの結果と考えられる。

図 16(b)は, 図 16(a)のノズル出口近傍以降を両 対数グラフ上に再プロットした結果である. $u_{c} / u_{0}$ は 下流に向かって, ポテンシャルコア領域 $(0 \leq x / h \leq 5)$, 遷移領域 $(5 \leq x / h \leq 9)$ 加発達領域 $(9 \leq x / h)$ 一と緩 やかに減衰し, 発達領域では 


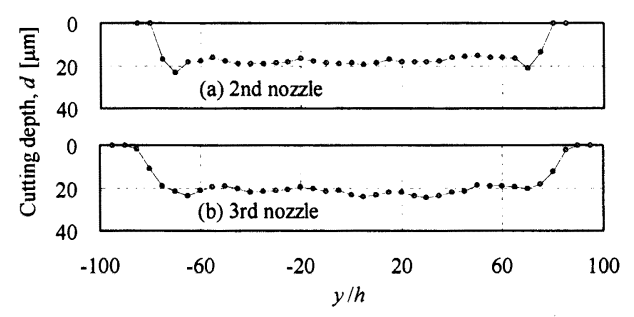

Fig. 17 Cutting cross section of 2nd and 3rd nozzles

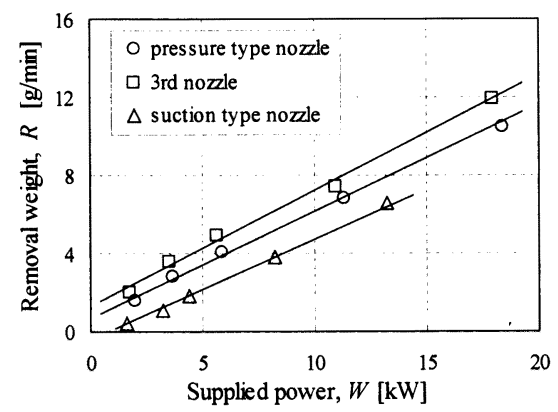

Fig. 18 MBP efficiency

$$
u_{c} / u_{0} \propto(x / h)^{-0.5} \text {. }
$$

となり, 二次元自由噴流の結果(5) と一致する. $u_{p c} / u_{0}$ は，ほぼ一定の緩やかな傾きで加速される加速領域 $(0 \leq x / h \leq 30)$, 遷移減速領域 $(30 \leq x / h \leq 70)$, および減 衰領域 $(x / h \geq 70)$ とに分けることができる，減衰領域 の減衰率は，気体のそれとほほ同様である。

計算結果は, 実験結果と同様の分布形となり, 緩や かに加速して極大值をとり，その後減少する.

$4 \cdot 3 \cdot 6$ 加工性能 図 17 に, 第 2 , 第 3 ノズルの 場合の加工断面形状を示す，ノズル出口幅が大きくな るとともに図 8(b) に示した両端部の加工過多形状が 低隇され, 平坦な加工形状を示す. 第 3 ノズルでは, $-70 \leq y / h \leq 70$ の範囲で加工精度 $\zeta= \pm 8.9 \%$ という 高精度な值を示した. 粒子分散とそれを要因とする粒 子速度の幅方向均一化および気体速度の均一化によ り，広範囲で高精度な加工が実現した。

4・3・7 加工効率図 18 に, 従来形ノズル(図 2) と本研究で新たに提案した第 3 ノズルの運転動力と加 工量との関係を示す.

第 3 ノズルは従来形ノズルと比較し所定の運転動力 下で最も加工量が大きく, 図 2(b)のノズルと比べ例 えば運転動力 $W=10 \mathrm{~kW}$ の場合で約 $15 \%$ の加工効率 向上が見られる.

MBPでは被削材に衝突し除去加工を行った後の粒 子が排出されることも加工効率向上の重要な一要素で ある.すなわち, 粒子が被削材に衝突した後その排出
が滞る場合には, 停滞した粒子の上に粒子が衝突する ことになり, 除去加工は行われにくくなる. 従来形の 加圧ノズルの流動抵抗は小さいが, 粒子群が 1 箇所に 集中しその排出が非効率的であるのに対し, 第 3 ノズ ルでは衝突スポットが狭いため, 衝突粒子の排出がよ り容易に行われるものと考えられる. その結果, 第 3 ノズルの加工効率がよくなると考えられる.

\section{5. 結 論}

本研究では, マイクロブラスト加エでワークの大き な面積を高精度に効率よく加工するために, 幅の広い 噴射口を有する二次元形状の矩形断面ノズルを新たに 提案し, ノズルからの高速空気噴流の流動特性, 微粉 粒子の挙動とワークの加工特性を実験的, 数值解析的 に検討した，得られた主な結果を以下に要約する.

（1）ノズル内に円柱形状ベーンを用いると粒子の 濃度分布, 速度分布が均一となり, MBPにおいて加 工精度が向上し, また被削材への衝突後の粒子間干涉 の低減, MBP 時の粒子排出が促進され, 加工効率が 向上する.

（2）気体噴流の速度分布は第 1 ノズルで鞍形を示 し，均一性は得られないが，ノズル角度を広げた第 2 , 第 3 ノズルでは広い範囲で平坦な分布となる。また, ノズル端部で粒子の拡散が促進され, 結果として MBP で $-70 \leq y / h \leq 70$ の範囲で高加工精度 $\pm 8.9 \%$ が得られる。

（3）気体の流れはノズル出口で最大速度を示す が, 粒子はその慣性力が大きいのでノズル出口の下流 $y / h=40$ で最大值を示す. また, ノズル出口での粒子 速度は気体速度の約 $20 \%$ にしか加速されない.

（4）第 3 ノズルの加工効率は, 従来形の MBP 加 工ノズルと比べ粒子間干涉の低減と MBP 加工時の粒 子の排出の促進により向上し, 例えば運転動力 $W=$ $10 \mathrm{~kW}$ のとき約 $15 \%$ 向上する.

本研究に協力いただいた, 三重大学学生 岡崎元紀 氏に感謝の意を表す。

\section{文献}

（1）平山正之・伊澤守康・北嶋弘一, マイクロブラスト工法, 砥粒加工学会誌, 46-3 (2002), 111-115.

（2）濱宗宏・小川信夫，二次元旋回ブラストノズルの研削性 能, 機講演 (流体工学部門), (1999), 413-414.

(3) Blevins, R. D., Applied fluid dynamics handbook, (1984), 153-155, Van nostrand reinhold company.

(4) Tollmien, W., Berechnung turbulenter Ausbreitungsvorgaenge, Z. Angew. Math. Mech, 6 (1926), 468-478.

(5) Krothapalli, A., Baganoff, D. and Karamcheti, K., On the mixing of a rectangular jet, J. Fluid Mech., 107 (1981), 201-220. 